\title{
Subjective Effects of Lemon Seed, Rose and Lavender Essential Oils on Humans: A Case Study from Two Different Age Groups
}

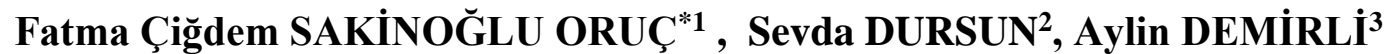

${ }^{1}$ Çilimli Meslek Yüksek Okulu, Düzce Üniversitesi, Düzce, Turkey

${ }^{2}$ Çilimli Meslek Yüksek Okulu, Düzce Üniversitesi, Düzce, Turkey

${ }^{3}$ Çilimli Meslek Yüksek Okulu, Düzce Üniversitesi, Düzce, Turkey

Received: 02 May 2017 - Revised: 11 July 2017 - Accepted: 03 September 2017

\begin{abstract}
Plant volatile oils have been used for different purposes for years, especially in the scientific and commercial areas. Among the major areas of their uses were the cosmetic, pharmaceutical and food industries, and the aroma/phyto therapeutic applications. The lemon seed, rose and lavender oils were the most commonly used oils and their effects on humans also differed individually. In this study, effects of these essential (volatile) oils on two age groups, 17-24 and 25-40 were thus investigated. The study was conducted on 80 people for one hour and the effects were evaluated using questionnaires. We used SPSS method for statics. In 17-25 age group, lavender oil caused drowsiness and weakness in $60 \%$ and $50 \%$ of respondents respectively, and also some mild giddiness, nausea, headache and dizziness. In 25-40 age group it caused giddiness and weakness in $40 \%$ respondents, and also gave mild vigor and tranquility. Lemon seed oil caused drowsiness in $85 \%$, weakness and headache in $50 \%$, and clear sensation in 55\% of the respondents from 17-24 age group, while in 25-40 age group it caused clear sensation in $80 \%$ of respondents, and gave the mood of tranquility in $70 \%$ and happiness in $60 \%$. However, rose oil demonstrated more intense effects on people, causing drowsiness and nausea in 55\%, weakness and headache in 50\%, and also giddiness, face flush and palpitation in 17-24 age-group-respondents. In 25-40 age group it caused drowsiness and nausea in $40 \%$ while it gave happiness and tranquility in $60 \%$ of respondents. Study results indicated that effects of different types of volatile oils on humans vary based on the age groups. So, the preference of essential oils in our daily lives is implied to have great importance. Therefore, further studies on the subject should be conducted to better emphasize the choice and use of these oils based on the age groups.
\end{abstract}

Keywords: Lemon seed oil, Rose oil, Lavender oil, Subjective, Human

\section{INTRODUCTION}

The natural treatment methods based on the use of aromatic or essence oils from plants are called "aromatherapy". The use of these oils covers wide range of areas such as from cosmetics industry to the medical applications. Their use also extend back to around $5000 \mathrm{BC}$ [1]. The term 'aromatherapy' was first introduced by the French biochemist Renee-Maurice Gattefosse in 1937. Lately, more studies have been conducted on the essential oils and number of these studies is also ever-increasing [2].

\footnotetext{
*Corresponding Author E-mail: cigdemsakinoglu@duzce.edu.tr
} 
In our daily lives, we experience the effects of aromatherapy unconsciously, for instance, with soil smell after rain and smell of fresh bread etc. However, systematic aromatherapy application is based on the principle that plants are employed in treatment using their highdensity essential oils and smells. In aromatherapy born from the ancient Egypt and Indian civilizations centuries ago, essential oils were often combined with the therapeutic effect of massage [3-4].

More than 60 different types of medicinal herbs have been used in aromatherapy. The most well-known aromatic plants include lavender oil, sweet orange oil, rose oil, jojoba oil, olive oil, geranium, sage, juniper, jasmine, sandalwood, eucalyptus and various incense.It has been reported that aromatherapy maintains the body and soul balance, provides the relaxation with pleasant odor, reduces the anxiety, fear, pain, nausea and vomiting, and increases the sense of well-being [5-7]. The only substance that able to pass through brain membrane is volatile oils. Thus, this transition has been very important in terms of treatment. For example, orange oil inhaled by smell gives cheerfulness, refreshes mind and relaxes depression, lavender oil relieves insomnia and headache, and rose oil removes postpartum depression, regulates menstrual period and relieves menopause complaints [8].

Pure essential oils have various effects on living organisms. They may aid in emotion and emotion-state control, function as anxiolytic [9] and antidepressant [10], and provide arousal [11], memory enhancement [12] and correction of cognitive impairment in dementia-related illnesses [13]. These effects are mediated by linkages extending to limbic system and hypothalamus through major olfactory tract, tractus olfactorius $[9,14]$. Natural rose oil includes ingredients like citranellol, geraniol, nerol, eugenol, methyl eugenol and phenylethyl alcohol [15]. Rose essence oil is also used for its calming effect and skin care in addition to its good fragrance [16,17]. Natural lavender oil contains linalool, linalyl acetate, lavandulyl acetate, Zocimene and caryophyllene. Lemon seed oil includes D-limonene as terpene [18].

Thus, effects of essential oils on humans have been important. In this regard, this work was attempted to investigate the effects of lavender, rose and lemon seed oils on two different age groups.

\section{MATERIAL and METHODS}

In this work, the effects of essential oils on two different age groups 17-24 and 25-40 were investigated. Study was performed on 80 people for one hour in the morning at 9:30-10:30 am. Each individual was tested on a separate day but at the same time. On the first day, rose oil was dropped in the room and subjects were exposed for one hour. Similarly, on the second and third days respectively, subjects were exposed to the lavender and lemon seed oils for one hour. Then, results were evaluated using questionnaires. Respondents were surveyed about 14 questions about fatigue, facial flushing, drowsiness, dizziness, giddiness, nausea, headache, palpitation, hallucinations, visual disturbances, happiness,clear sensation, peace and vigority. They were then asked to assess the questions on a scale of 1 to 10 . Values 1-5 were classified as too low, values 5-7 were as medium strength and values 7-10 were as very strong for the tested effects. Subsequently, all questionnaires were re-evaluated based on the effects seen as either "with-impact" or "without-impact". The surveyed questionnaire is given in Table 1. 
Table 1. Surveyed Questionnaire

\begin{tabular}{|c|c|c|c|c|c|c|c|c|c|c|}
\hline Essential oil & \multicolumn{3}{|c|}{ Lavandula } & \multicolumn{4}{|c|}{ Lemon Seed } & \multicolumn{3}{|c|}{ Rose } \\
\hline Age & \multicolumn{3}{|c|}{$17-24$} & & & & \multicolumn{4}{|c|}{$\begin{array}{l}\text { Kose } \\
25-40\end{array}$} \\
\hline \multirow{2}{*}{ Symptoms seen } & \multicolumn{10}{|c|}{ RATING } \\
\hline & 1 & 2 & 3 & 4 & 5 & 6 & 7 & 8 & 9 & 10 \\
\hline \multicolumn{11}{|l|}{ Perception openness } \\
\hline \multicolumn{11}{|l|}{ Fatigue } \\
\hline \multicolumn{11}{|l|}{ Sleeping state } \\
\hline \multicolumn{11}{|l|}{ Dizziness } \\
\hline \multicolumn{11}{|l|}{ Drowsiness } \\
\hline \multicolumn{11}{|l|}{ Nausea } \\
\hline \multicolumn{11}{|l|}{ Headache } \\
\hline \multicolumn{11}{|l|}{ The palpitation } \\
\hline \multicolumn{11}{|l|}{ The hallucination } \\
\hline \multicolumn{11}{|l|}{ Facial flush } \\
\hline \multicolumn{11}{|l|}{ Happiness } \\
\hline Peace & & & & & & & & & & \\
\hline
\end{tabular}

\section{RESULTS}

\subsection{Lavender Oil}

Lavender oil is known to be a good antiseptic and it is also reported to maintain the body and soul balance, help the relaxation with pleasant odor, relieve the anxiety, fear, pain, nausea and vomiting, and increase the sense of well-being. Herein, effects of lavender oil on 17-24 and 25-40 age groups seemed to differ from each other. In questionnaires responded by 17-24 age group, from 40 people, $\% 60$ respondents reported for drowsiness and $\% 50$ respondents reported for fatigue. Besides, these effects were also seen in the same people. In addition, lavender oil also caused some mild giddiness, dizziness and headache in the subjects. No other adverse effects like facial flushing, palpitation, nausea, hallucinations and visual disturbances were observed, and young group did not also see positive effects such as peace, vigority and clear sensation. On the other hand, in 25-40 age group, the intensity of effects decreased, out of 40 respondents, $\% 40$ observed drowsiness and fatigue, and \%23 reported for vigority and peace [Table 2].

Table 2. Analysis Results for Lavander Oil

\begin{tabular}{lcc|cc|cc|cc}
\hline & \multicolumn{3}{c}{$17-24$} & \multicolumn{5}{c}{$25-40$} \\
\hline & $<5$ & $\%$ & $>5$ & $\%$ & $<5$ & $\%$ & $>5$ & $\%$ \\
\hline Perception openness & 36 & 90 & 4 & 10 & 38 & 95 & 2 & 5 \\
Fatigue & 20 & 50 & 20 & 50 & 24 & 60 & 16 & 40 \\
Sleeping state & 24 & 60 & 16 & 40 & 20 & 50 & 20 & 50 \\
Dizziness & 40 & 100 & 0 & 0 & 38 & 95 & 2 & 5 \\
Drowsiness & 24 & 60 & 16 & 40 & 24 & 60 & 16 & 40 \\
Nausea & 36 & 90 & 4 & 10 & 32 & 80 & 8 & 20 \\
Headache & 32 & 80 & 8 & 20 & 34 & 85 & 6 & 15 \\
The palpitation & 36 & 90 & 4 & 10 & 40 & 100 & 0 & 0 \\
The hallucination & 36 & 90 & 40 & 10 & 40 & 100 & 0 & 0 \\
Facial flush & 32 & 80 & 8 & 20 & 40 & 100 & 0 & 0 \\
Happiness & 36 & 90 & 4 & 10 & 40 & 100 & 0 & 0 \\
Peace & 32 & 80 & 8 & 20 & 31 & 77 & 9 & 23 \\
Vigor & 32 & 80 & 8 & 20 & 31 & 77 & 9 & 23 \\
\hline
\end{tabular}


Lavender essential oil contains $23.29 \%$ camphor, $10.87 \%$ phencon, $4.07 \%$ eucalyptol, and $1.5 \%$ linalool and linalyl acetate [19]. Thus, negative effects like dizziness, nausea and giddiness, particularly in the young age group could be caused by these oil ingreidents. On contrary, adverse effects in the middle age group are reduced and relaxing effects appear.

\subsection{Rose Oil}

Pure rose oils have various effects on the emotion and emotion-state control, anxiety, depression, arousal, memory enhancement and in amelioration of cognitive impairment in dementia. Some essential oils applied via respiration and orally were also reported to reduce the symptoms and strengthen the memory in neurodegenerative diseases like Alzheimer $(7,14)$. In this work, different effects were observed in the studied age groups. In 17-24 age group, out of 40 people, $\% 55$ respondents had an intense nausea and drowsiness while $\% 50$ respondents reported for headaches and weakness. Besides, respondents also reported for some mild face flushing, giddiness and palpitations. On the other hand, in 25-40 age group, only \%40 subjects -from 40 respondents- had these negative effects. Besides, rose oil essence also created happiness and peace in $\% 60$ subjects [Table 3].

Natural rose oil contains substances like citranellol, geraniol, nerol, eugenol, methyl eugenol and phenylethyl alcohol [15]. 85\% of these substances fall under a group called citronellal, consisting of citronellal, neral and nerol. This group has allergic effect and also has soothing effect especially in the intense environments (environments with high temperature, humidity etc.). Thus, effect of citranellol has become a major cause of adverse effects especially in young people, whereas phenylethyl alcohol increased the peace and happiness in the middle age group.

Table 3. Analysis Results for Rose Oil

\begin{tabular}{lcc|cc|ccc|cc}
\hline & \multicolumn{9}{c}{$17-24$} \\
\hline & $<5$ & $\%$ & $>5$ & $\%$ & $<5$ & $\%$ & $>5$ & $\%$ \\
\hline Facial flush & 28 & 70 & 12 & 30 & 40 & 100 & 0 & 0 \\
Weakness & 20 & 50 & 20 & 50 & 32 & 80 & 8 & 20 \\
Sleeping state & 18 & 45 & 22 & 55 & 24 & 60 & 16 & 40 \\
Dizziness & 22 & 55 & 18 & 45 & 32 & 80 & 8 & 20 \\
Clear Sensation & 26 & 65 & 14 & 35 & 32 & 80 & 8 & 20 \\
Nausea & 19 & 45 & 21 & 55 & 24 & 60 & 16 & 40 \\
Headache & 20 & 50 & 20 & 50 & 32 & 80 & 8 & 20 \\
The palpitation & 30 & 75 & 10 & 25 & 40 & 100 & 0 & 0 \\
The hallucination & 36 & 90 & 4 & 10 & 40 & 100 & 0 & 0 \\
Disorder in sight & 36 & 90 & 4 & 10 & 10 & 100 & 0 & 0 \\
Happiness & 40 & 100 & 0 & 0 & 16 & 40 & 24 & 60 \\
Peace & 40 & 100 & 0 & 0 & 16 & 40 & 24 & 60 \\
Vigor & 40 & 100 & 0 & 0 & 36 & 90 & 4 & 10 \\
\hline
\end{tabular}

\subsection{Lemon Seed Oil}

Lemon seed oil has been a natural antioxidant source since it is rich in vitamin $\mathrm{C}$. This effect is especially useful in eliminating mental and physical fatigue. In questionnaires responded by 17-24 age group, from 40 people, \%85 respondents reported for drowsiness because of its relaxation effect while $\% 50$ respondents reported for fatigue. Besides, \%55 respondents also reported for clear sensation and vigority. On the other hand, in 25-40 age 
group, results were quite different; no negative effect was reported by respondents, on contrary, $\% 72$ people had clear sensation, $\% 63$ people had peace and $\% 57$ people had happiness [Table 4].

Lemon seed oil contains 34,34-43,59\% linoleic, 20,65-28,48\% oleic and 23,72-30,33\% palmitic acids. These fatty acids serve as energy storage facility. Especially they help to improve cell functions; in case of deficiencies the depression and behavioral disorders can occur. Thus, effects of their odor on humans emerged quite clearly.

Table 4. Analysis Results for Lemon Seed Oil

\begin{tabular}{lcc|cc|ccccc}
\hline & \multicolumn{4}{c}{$17-24$} & \multicolumn{6}{c}{$25-40$} \\
\hline Clear Sensation & $<5$ & $\%$ & $>5$ & $\%$ & $<5$ & $\%$ & $>5$ & $\%$ \\
Weakness & 19 & 47 & 21 & 53 & 11 & 28 & 29 & 72 \\
Sleeping state & 6 & 50 & 20 & 50 & 40 & 100 & 0 & 0 \\
Dizziness & 38 & 95 & 25 & 85 & 28 & 70 & 12 & 30 \\
Perception openness & 24 & 60 & 16 & 40 & 40 & 100 & 0 & 0 \\
Nausea & 32 & 80 & 8 & 20 & 40 & 100 & 0 & 0 \\
Headache & 20 & 50 & 20 & 50 & 32 & 80 & 8 & 0 \\
The palpitation & 40 & 100 & 0 & 0 & 40 & 100 & 0 & 0 \\
The hallucination & 40 & 100 & 0 & 0 & 40 & 100 & 0 & 0 \\
Disorder in sight & 40 & 100 & 0 & 0 & 20 & 50 & 20 & 50 \\
Happiness & 32 & 80 & 8 & 20 & 17 & 43 & 23 & 57 \\
Peace & 30 & 75 & 10 & 25 & 15 & 37 & 25 & 63 \\
Vigor & 19 & 47 & 21 & 53 & 32 & 80 & 8 & 20 \\
\hline
\end{tabular}

\section{CONCLUSION}

Present study has demonstrated the effects of essential oils on different age groups and these effects on the subjects differed individually. The active ingredients of tested oils led more intense negative effects the on the 17-24 age group. In 25-40 age group, these oils caused negative effects as well as positive subjective effects like happiness, peace, vigority and clear sensation. The presence of lavender oil in the environment brought about its effects as dizziness and giddiness, while rose oil caused the effects of nausea, facial flushing and palpitation. Besides, lemon seed oil has no negative effects, other than drowsiness and fatigue, on the 1724 age group, while in 25-40 age group the effects have been more positive, with responses about increased clear sensation, happiness and peace.

Thus, preference of essential oils being used in our daily lives is of great importance. So, further studies should be conducted to better elucidate the effects of those essential oils on individuals/age groups as well as to understand their health implications on humans.

\section{REFERENCES}

[1] Umezu, T. (2000). Behavioral effects of plant-derived essential oils in the Geller type conflict test in mice. Jpn J Pharmacol, 83, 150-153

[2] Lis-Balchin, M. (1998). Essential oils and 'aromatherapy': their modern role in healing. $J$ $R$ Soc Health; 118, 126.

[3] Hobbs, L. (2001). The Best Labor Possible? 1th. Edition, Edinburgh: Elsevier Science Limited, 60-102. 
[4] Simkin, P., \& Boldig, A. (2004). Update on nonpharmacologic approaches to relieve labor pain and prevent suffering. J Midwifery Womens Health, 49, 489-504.

[5] Cooke B., \& Ernest E. (2000). Aromatherapy: a systematic review. Br J Gen Pract, 50, 493-496.

[6] Imanishi, J., Kuriyama, H., Shigemori, I., Watanabe, S., Aihara, Y., Kita M, Sawai, K., Nakajima, H., Yoshida, N., Kunisawa, M., Kawase, M., Fukui, K. (2009). Anxiolytic effect of aromatherapy massage in patients with breast cancer. eCAM, 6, 123-128.

[7] Kuriyama, H., Watanabe, S., Nakaya, T., Shigemori, I., Kita, M., Yoshida, N., Masaki, D., Tadai, T., Ozasa, K., Fukui, K., Imanishi, J. (2005). Immunological and psychological benefits of aromatherapy massage. eCAM, 2, 179-184.

[8] Toroğlu, S., \& Çenet, M. (2006). KSÜ Fen ve Mühendislik Dergisi, 9(2), 12-20.

[9] Carvalho-Freitas, M. I., \& Costa, M. (2002). Anxiolytic and sedative effects of extracts and essential oil from Citrus urantium L.. Biol Pharm Bull, 25, 1629-1633.

[10] Komori, T., Fujiwara, R., Tanida, \& M, Nomura, J. (1995). Potential antidepressant effects of lemon odor in rats. Eur Neuropsychopharmacol, 5, 477-480.

[11]Diego, M. A., Jones, N.A, Field T, \& et al. (1998). Aromatherapy positively affects mood. EEG patterns of alertness and math computations. Int J Neurosci, 96, 217-224.

[12] Oh, M. S., Huh, Y., Bae, H., Ahn, D. K., \& Park, S. K. (2005). The multi-herbal formula Guibi- tang enhances memory and increases cell proliferation in the rat hippocampus. Neurosci Lett, 379, 205-208.

[13] Howes, M. J., Houghton, P.I. (2003). Plants used in Chinese and Indian tradational medicine for improvement of memory and cognitive function. Pharmacol, Biochem Behav, 75, 513-527.

[14] Savic, I., Berglund, H., Gulyas, B.,\& Roland, P. (2001). Smelling of Odorous Sex Hormone-like Compounds Causes Sex- ifferantiated Hypothalamic Activations in Humans. Neuron, 31, 661- 668.

[15]Kurkcuoğlu, M. (1995). Turk Gul Yağı, Konkreti ve Absolusunun Uretimi ve Ozellikleri. Doktora Tezi, Eskisehir: Anadolu Universitesi Sağlık Bilimleri Enstitusu, Farmakognozi AD.

[16]Basim, E., \& Basim, H. (2003). Antibacterial activity of Rosa damascena essential oil. Fitoterapia, 74, 394-396.

[17]Demir, F., \& Ozcan, M. (2001). Chemical and technological properties of rose (Rosa Canina L.) fruits grown wild in Turkey. J Food Eng, 47, 333-336.

[18] Morton, J. (1987). Lemon. In: Fruits of warm climates. Ed. JF Morton. Miami, FL, pp. 160- 68.

[19] Tanker, N., Şarer, E. \& Başaran, V.(1977). Lavandula stoechas L. Bitkisinin Uçucu Yağ1 Üzerinde Farmakognozik Araştırmalar. Ankara Üniversitesi Eczacılık Fakültesi Mecmuast, 7, 61-66. 